\title{
Additions to the Systematic Inventory of Non-Marine Molluscs Occurring in the State of Santa Catarina/SC, Central Southern Brazil Region
}

\author{
A Ignacio Agudo-Padrón* \\ Geographer, Researcher Malacologist, Project "Avulsos Malacológicos-AM", Brazil
}

\begin{abstract}
Based on the last list of non-marine molluscs from Santa Catarina State/SC published in March 2018, with 232 related forms, the current inventory of continental molluscs (land/terrestrial and limnic/freshwater) occurring in the State of Santa Catarina/SC is increased, with a new verified/confirmed registry of most other twenty (20) species (-fifteen (15) gastropods, thirteen (13) natives-Pomacea maculata Perry, 1810; Phyllocaulis sp (in determination process); Drepanotrema kermatoides (d'Orbigny, 1835); Anisancylus obliquus (Broderip \& Sowerby, 1832); Drymaeus cf. paucipunctus (Pilsbry, 1898); Leiostracus cf. polygrammus (Moricand, 1836); Leiostracus sp (in determination process); Omalonyx matheroni (Potiez \& Michaud, 1838); Peltella cf. palliolum (Férussac, 1821); Peltella iheringi Leme, 1968; Streptaxis cf. subregularis (Pfeiffer, 1846); Streptaxis cf. tumescens Suter, 1900; Gastrocopta cf. servilis (Gould, 1843); and two (2) non-native/exotic invasives forms - Ovachlamys fulgens (Gude, 1900); Galba (-Lymnaea) truncatula (Müller, 1774); ...besides five (5) native bivalves-Diplodon charruana (d'Orbigny, 1835); Diplodon (-Rhipidodonta) suavidicus (Lea, 1856); Musculium argentinum (d'Orbigny, 1835); Eupera bahiensis (Spix, 1827); Cyanocyclas paranacensis (d'Orbigny, 1835) -), for a new total verified/ confirmed registry of 252 species and subspecies, sustained/consolidated product of complete 24 years of systematic field researches, examination of specimens deposited in collections of museums and parallel reference studies. Additional information regarding its known regional geographic distribution is incorporated/included.
\end{abstract}

\section{Keywords}

Continental (land \& freshwater) molluscs, Santa Catarina State, Central Southern Brazil region, Additions to the species inventory

\begin{abstract}
Abbreviations
CEMAR: Centre for Marine Studies, Bombinhas Museum and Marine Aquarium, Bombinhas/SC; FURBMO: Malacological Collection of Fundação Universidade Regional de Blumenau; LMSM: Laboratório de Malacologia e Sistemática Molecular (Laboratory of Malacology and Molecular Systematics), Zoology Department of Universidade Federal de Minas Gerais, Belo Horizonte/MG
\end{abstract}

Continuing the researches conducted since the year 1996, the present contribution incorporates a new verified/confirmed registry of most other twenty (20) species of continental molluscs (ten (10) land/terrestrial, one (1) amphibious/ limnophile and nine (9) limnic/freshwater-four (4) gastropods \& five (5) bivalves) to the systematic inventory of the State of Santa Catarina/SC previously established [1], sustained product of complete 24 years of systematic field researches, examination of specimens deposited in collections of museums and parallel reference studies, increasing to 252 its number of registered forms regionally known [1].

The taxonomic, systematic and biogeographic (Figure 1Map) arrangement presented follow the previously established working parameters $(54,58)$ [1].

\section{Results}

\section{GASTROPODA Cuvier, 1795}

CAENOGASTROPODA Cox, 1960

*Corresponding author: A Ignacio Agudo-Padron, Geographer, Researcher Malacologist, CEO Project "Avulsos Malacológicos-AM", Brazilian NGO, PO Box: 010, 88010-970, Centro, Florianópolis city, Santa Catarina State/SC, Brazil

Accepted: February 22, 2020

Published online: February 24, 2020

Citation: Agudo-Padrón Al (2020) Additions to the Systematic Inventory of Non-Marine Molluscs Occurring in the State of Santa Catarina/SC, Central Southern Brazil Region. Adv Environ Stud 4(1):261-270

Copyright: (c) 2020 Agudo-Padron Al. This is an open-access article distributed under the terms of the Creative Commons Attribution License, which permits unrestricted use, distribution, and reproduction in any medium, provided the original author and source are credited. 


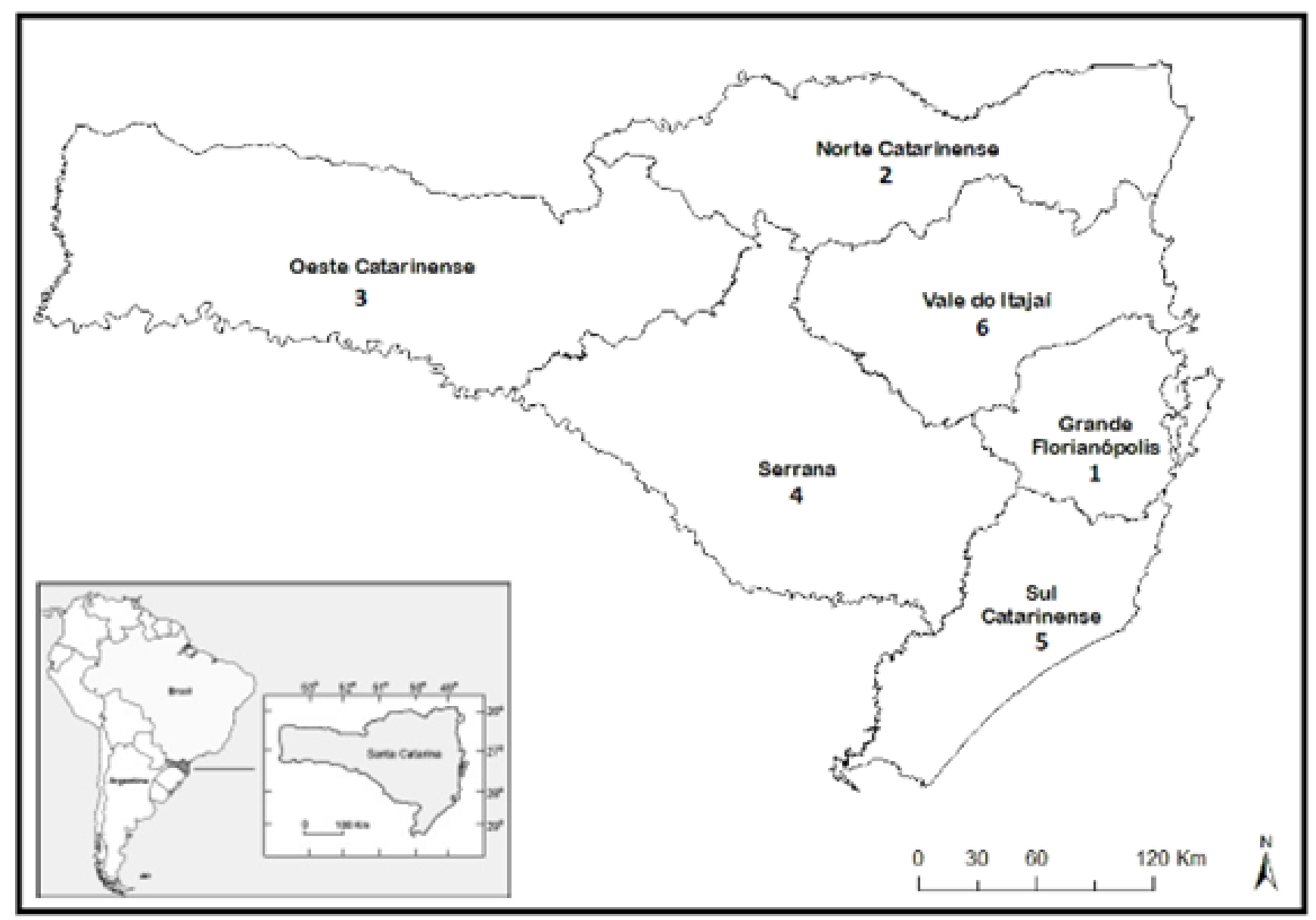

Figure 1: Malacological division of the Santa Catarina State/SC geographic territory: (1) Greater Florianópolis, coastal and mountain Region; (2) Northern Region; (3) Western Region; (4) Highlands Region; (5) Southern Region; (6) Itajaí River Basin Valley region. Credit Map: Original by A. Ignacio Agudo-Padrón, staff of the "Project AM".

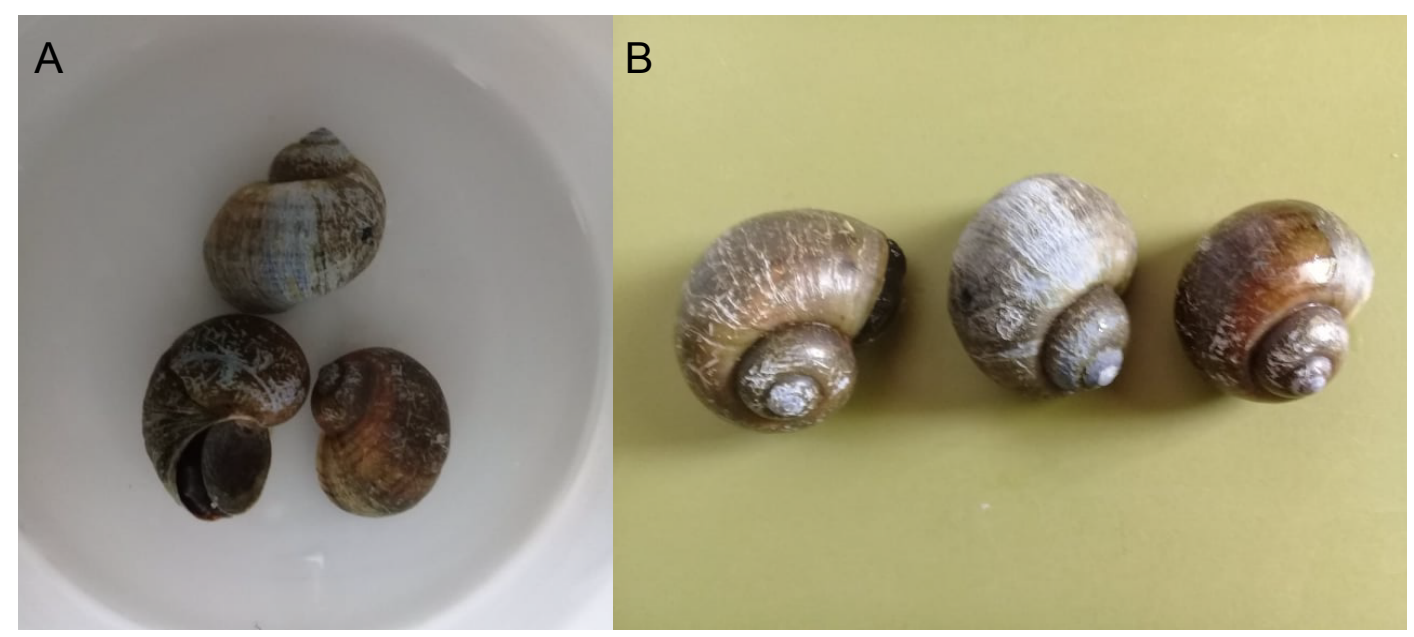

Figure 2: Native freshwater apple snail Pomacea maculata Perry, 1810.

Family AMPULLARIIDAE Gray, 1824

Pomacea maculata Perry, 1810 (Figure 2)

"Aguas Mornas" Municipal District $\left(27^{\circ} 41^{\prime} 38^{\prime \prime S ~ \& ~}\right.$ $\left.48^{\circ} 49^{\prime} 25^{\prime \prime} \mathrm{W}\right)$, Malacological region 1-Greater Florianópolis (Mountain sector), 27/01/2020, Specimens found in "sport fishing lake" located in the hydrothermal/thermo-mineral
SPA installation "Aguas Mornas Palace Hotel". Credit photos \& field report: "Ignacio Agudo", DataBase Project AM [2].

GYMNOPHILA Baker, 1955

Family VERONICELLIDAE Gray, 1840

Phyllocaulis sp (Figure 3) 


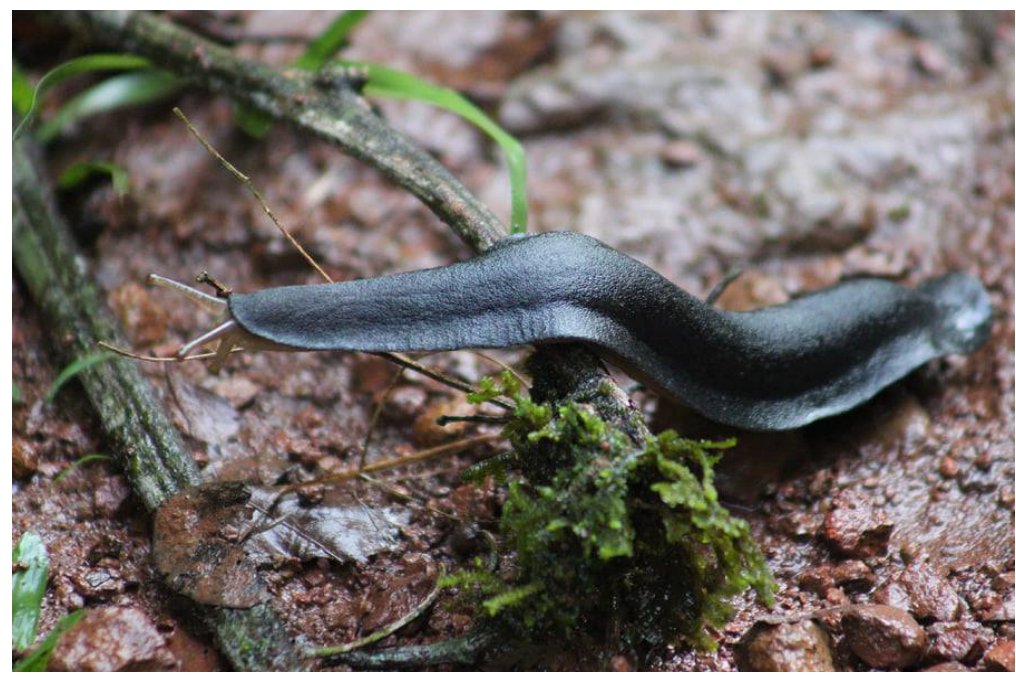

Figure 3: Native forest leatherleaf slug Phyllocaulis sp (in determination process).

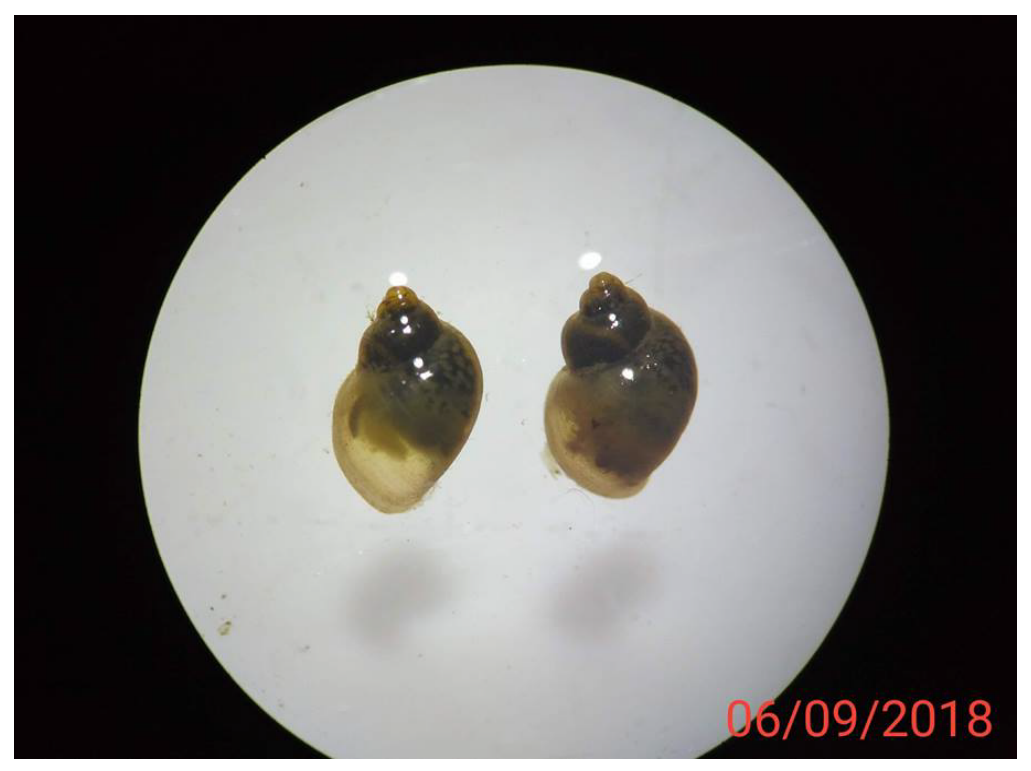

Figure 4: Exotic limnic snail Galba truncatula (Müller, 1774).

"Faxinal do Guedes" Municipal District $\left(26^{\circ} 51\right.$ '10"S \& $\left.52^{\circ} 15^{\prime} 36^{\prime \prime} W\right)$, Malacological region 3-Western, 29/10/2019, Specimen with aprox. $150 \mathrm{~mm}$, found in ciliar area of the "Chapecozinho River" $\left(26^{\circ} 46^{\prime} \mathrm{S} \& 52^{\circ} 37^{\prime} \mathrm{W}\right)$, principal tributary of the "Chapecó River" in the Uruguay River Basin Valley. Credit photo \& field report: "Douglas Meyer", DataBase Project AM.

\section{PULMONATA Cuvier, 1817}

Family SUCCINEIDAE Beck, 1837

Omalonyx matheroni (Potiez \& Michaud, 1838)

"Piçarras" (Vouchers LMSM 3942, 4024-4028), Malacological region 6 -- Itajaí Valley \& "Biguaçu" (Vouchers LMSM 3507, 3508), Malacological region 1 -- Great Florianópolis (Figure 1) [3,4]. LMSM: Laboratório de Malacologia e Sistemática Molecular (Laboratory of Malacology and Molecular Systematics), Zoology Department of Universidade Federal de Minas
Gerais, Belo Horizonte/MG.

Family LYMNAEIDAE Rafinesque, 1815

Galba (-Lymnaea) truncatula (Müller, 1774) (Figure 4)

"Benedito Novo" (Vouchers FURB-MO 354 \& FURB-MO 355), Blumenau Micro-region, Malacological region 6--Itajaí Valley [4,5]. FURB-MO: Malacological collection of Fundação Universidade Regional de Blumenau.

Family PLANORBIDAE Rafinesque, 1815

Anisancylus obliquus (Broderip \& Sowerby, 1832)

Drepanotrema kermatoides (d’Orbigny, 1835)

"Porto União" (Pintado River, tributary of the Iguaçu River), Malacological region 2-North (Figure 3) [6].

Family BULIMULIDAE Tryon, 1867

Drymaeus cf. paucipunctus (Pilsbry, 1898) (Figure 5) 
Citation: Agudo-Padrón Al (2020) Additions to the Systematic Inventory of Non-Marine Molluscs Occurring in the State of Santa Catarina/SC, Central Southern Brazil Region. Adv Environ Stud 4(1):261-270

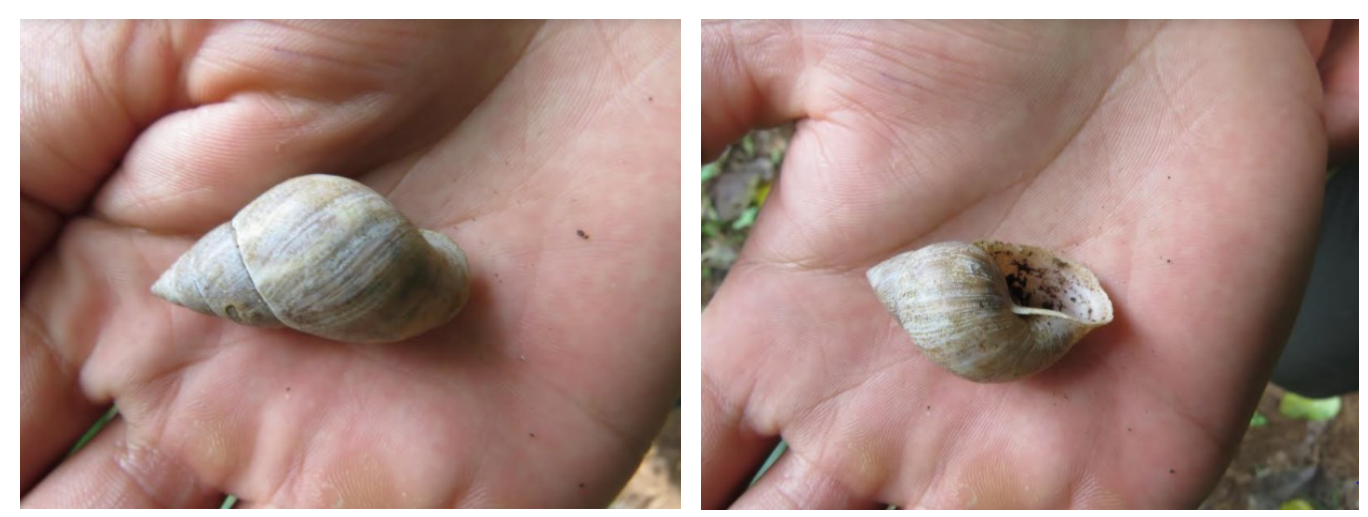

Figure 5: Native forest snail Drymaeus cf. paucipunctus (Pilsbry, 1898).

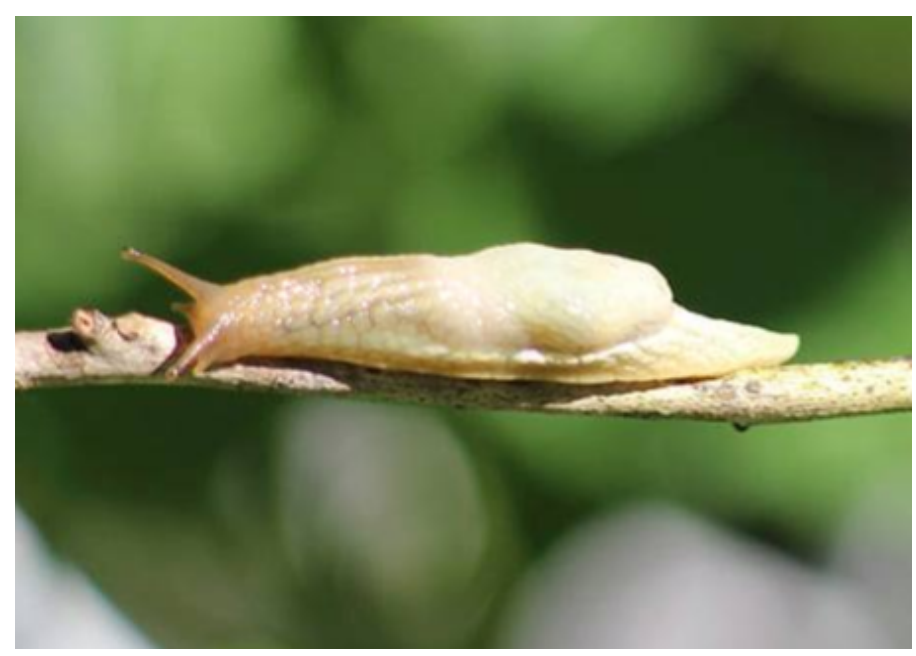

Figure 6: Native forest semi-slug Peltella iheringi Leme, 1968.

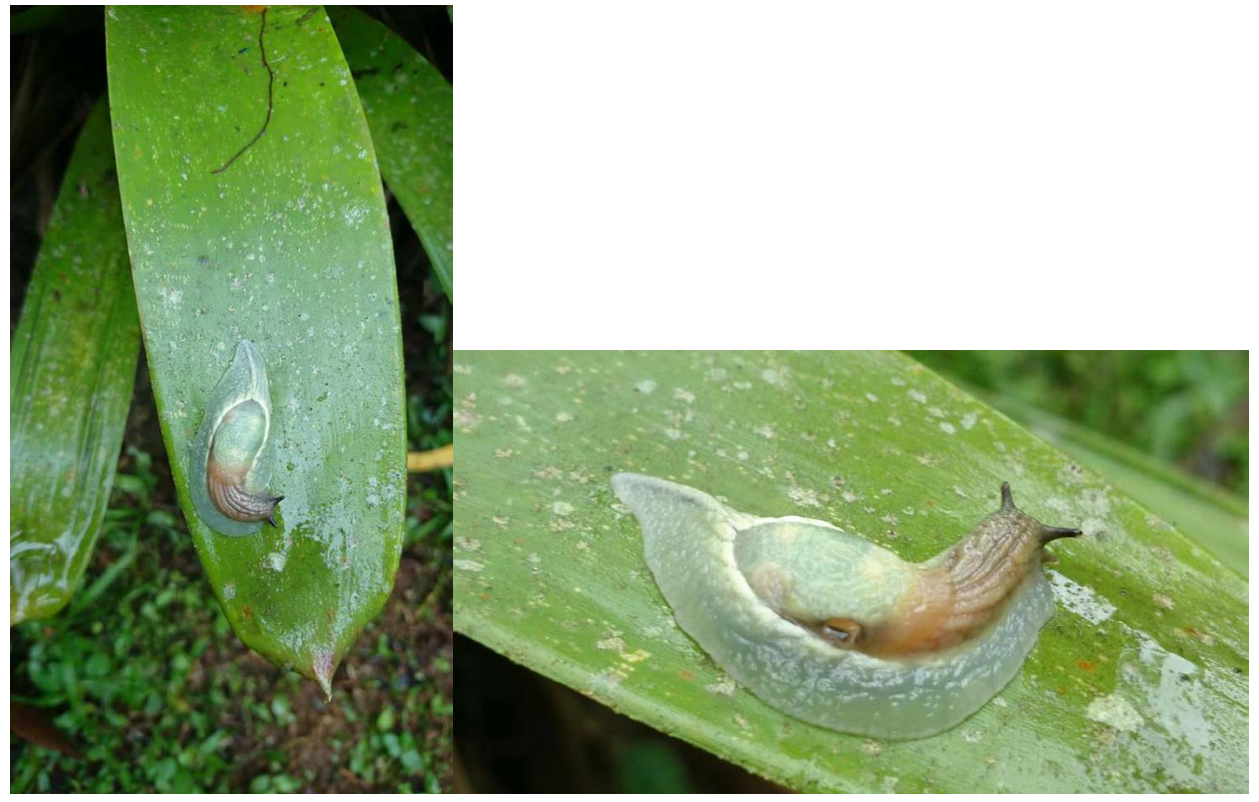

Figure 7: Native forest semi-slug Peltella cf. palliolum (Férussac, 1821).

“Linha Nova Teutônia” (2710'49.05"S \& 52²5'55.37"W), Malacological region 3-Western, 23/01/2020, Specimen found in riparian area of the "Ariranha River", tributary of the "Upper Uruguay River" in the Seara Municipal District. Cred- 


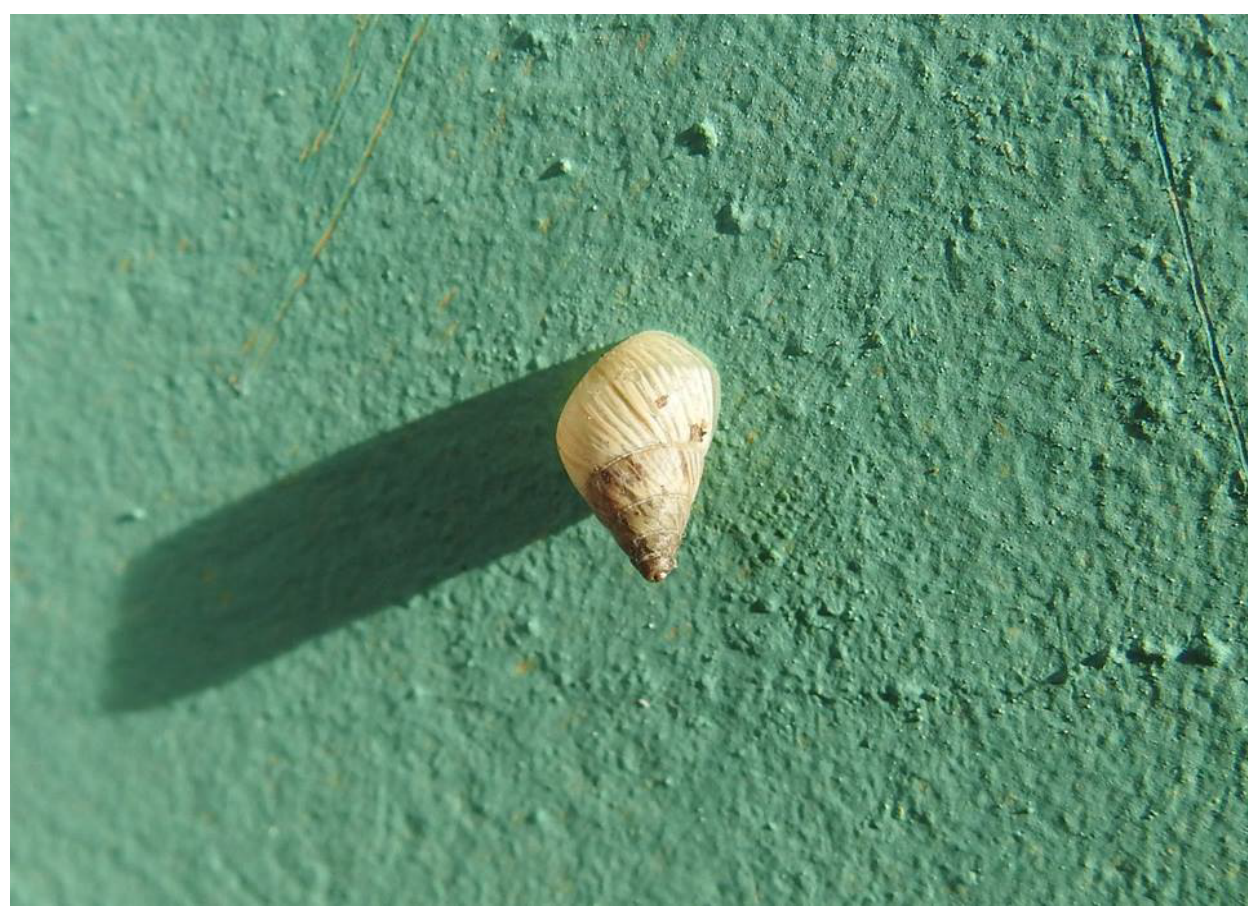

Figure 8: Native forest snail Leiostracus cf. polygrammus (Moricand, 1836).

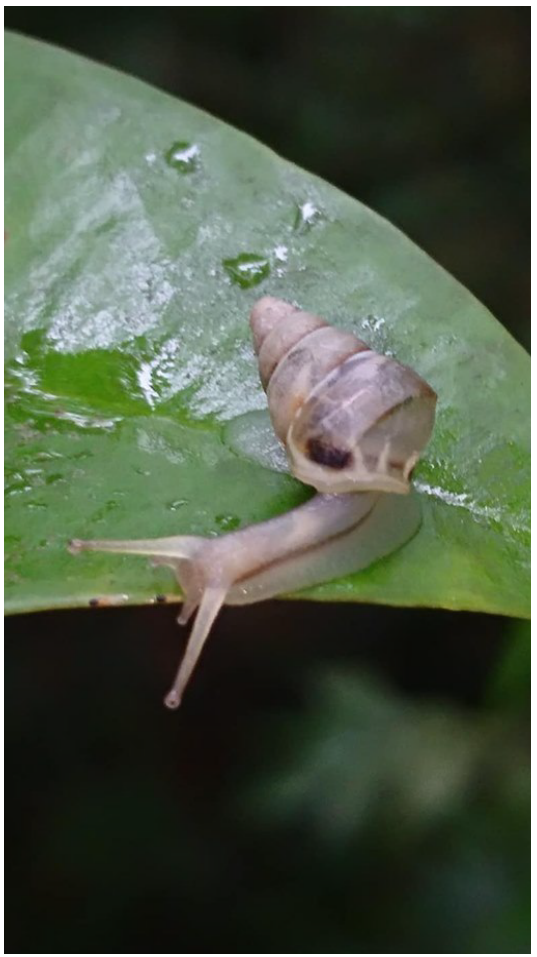

Figure 9: Native forest snail Leiostracus sp (in determination process)

it photo \& field report: "Emanueli Marin Albino", DataBase Project AM.

Family SIMPULOPSIDAE Schileyko, 1999

Peltella iheringi Leme, 1968 (Figure 6)

"Doutor Pedrinho", Malacological region 6-Itajaí Basin
Valley, 26/06/2019, Specimen with aprox. $30 \mathrm{~mm}$, found in local Forest environment to 530 meters above sea level. Credit photo \& field report: "Douglas Meyer", DataBase Project AM.

Peltella cf. palliolum (Férussac, 1821) (Figure 7)

"Joinville" (Dona Francisca Mountain Range Environmental Protection Area), Malacological region 2-North, 27/06/2018, Specimen with aprox. $40 \mathrm{~mm}$, found in well preserved Dense Ombrophylous Forest (on bromeliad leaf) to 300 meters above sea level. Credit photos \& field report: "Fábio Longen", DataBase Project AM [4].

Leiostracus cf. polygrammus (Moricand, 1836) (Figure 8)

"Praia Grande", Malacological region 5-South, 10/01/2019, Young specimen, found on a wall. Credit photo \& field report: "Amanda Perin Marcon", DataBase Project AM.

\section{Leiostracus sp (Figure 9)}

"Morro da Boa Vista" (Zoobotanical Park of Joinville), Malacological region 2-North, 22/07/2019, Specimen in determination process with aprox. $10 \mathrm{~mm}$, found to 250 meters above sea level in domain of Atlantic Slope Forest environment. Credit photo \& field report: "Fábio Longen", DataBase Project AM.

\section{Family STREPTAXIDAE Gray, 1806}

Streptaxis cf. subregularis (Pfeiffer, 1846)

"Urubici", Malacological region 4-Highlands, 13/10/2018. Credit photo \& report: ínaturalist Web DataBase < https:// www.inaturalist.org/observations/17510916? fbclid $=$ IWAROgDMIVVoCFNZzEQa2fZQnfNy_Doo4tLuCYyBdKFliAVQcxLyETt3y78tg >

Streptaxis cf. tumescens Suter, 1900 (Figure 10) 


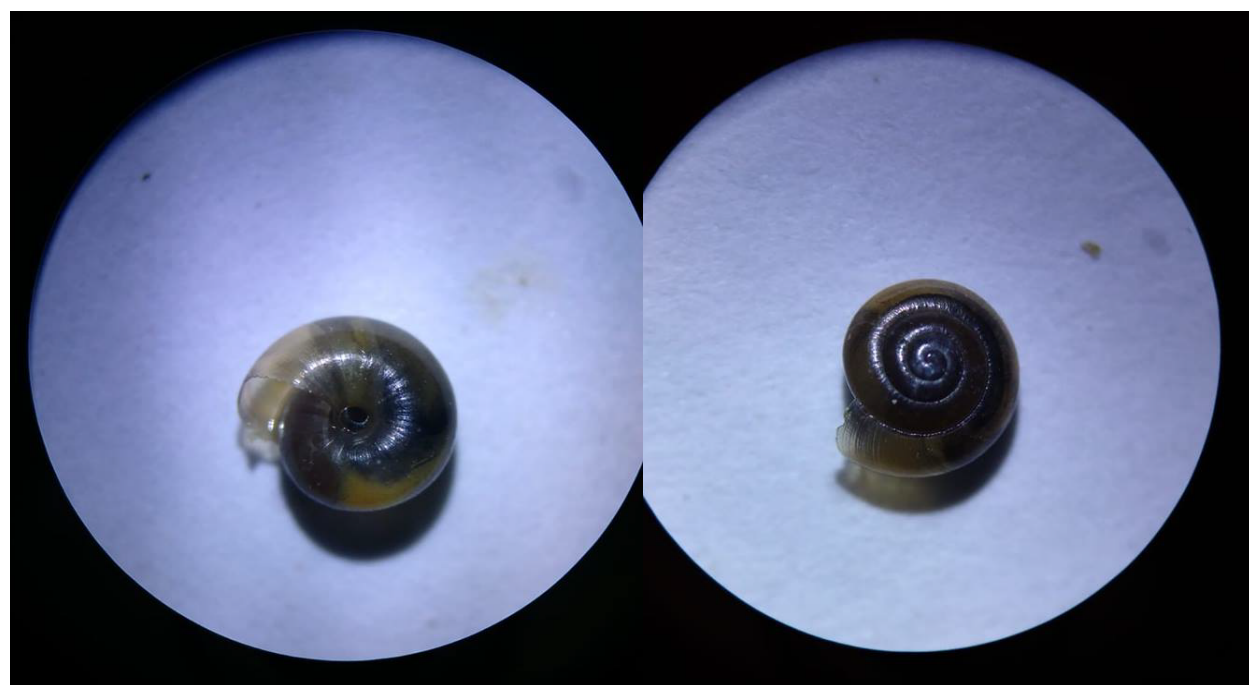

Figure 10: Native forest snail Streptaxis cf. tumescens Suter, 1900.

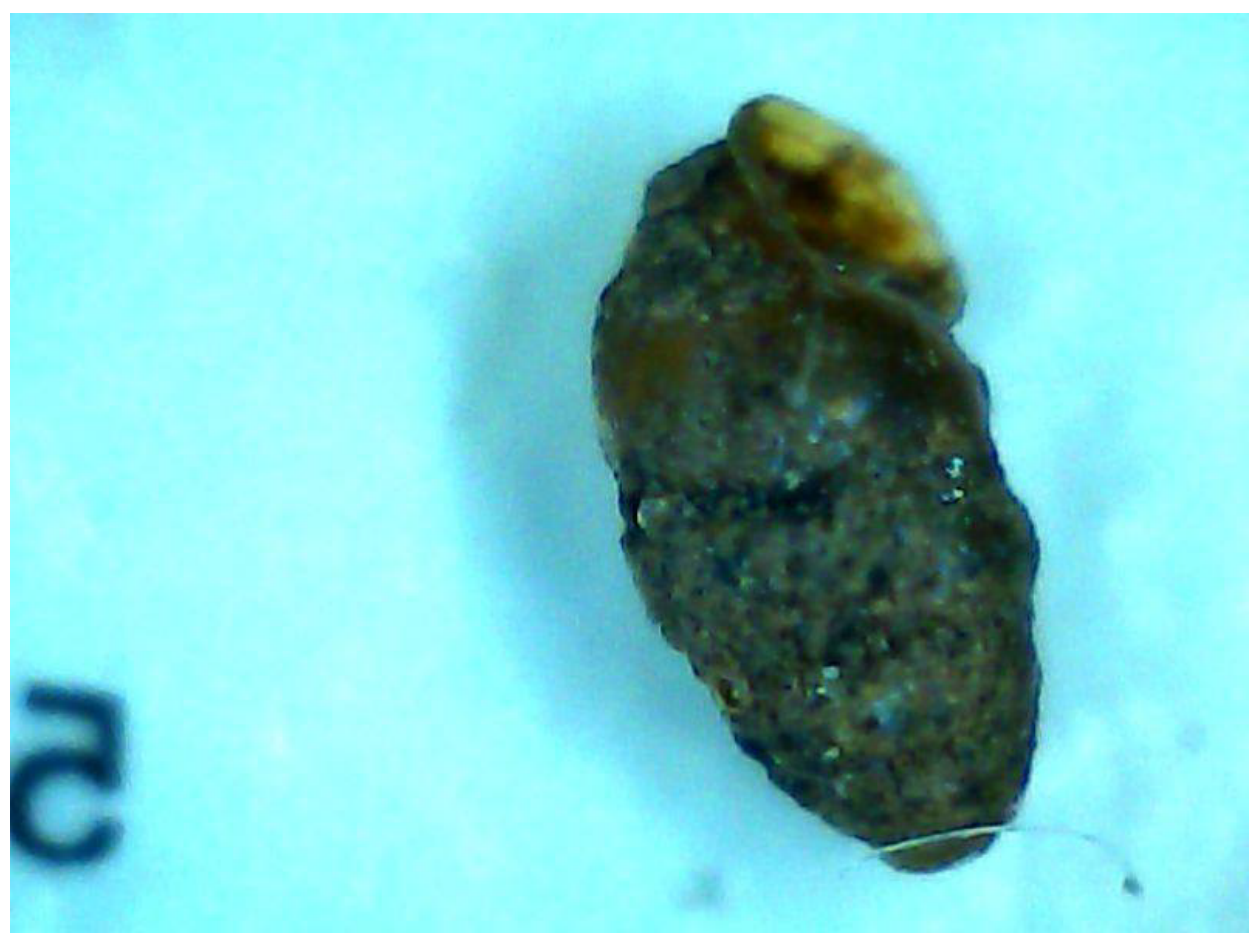

Figure 11: Native pupiform microsnail Gastrocopta cf. servilis (Gould, 1843).

"São José", Malacological region 1-Great Florianópolis, $02 / 11 / 2018$, Specimen with $4 \mathrm{~mm}$, found in ornamental plants verified (orchids genus "Oncidium" and "Catleya") sold in local floriculture. Credit photos \& field report: "Jefferson Souza da Luz", DataBase Project AM [4].

Family HELICARIONIDAE Bourguignat, 1877

\section{Ovachlamys fulgens (Gude, 1900)}

"Blumenau" (Voucher FURB-MO 179, eleventh (11) specimens), Malacological region 6--Itajaí Valley; "Bombinhas" (Voucher CEMAR 3176, two (2) specimens), Malacological region 6-Itajaí Valley; "Botuverá" (Field photo-report), Malacological region 6-Itajaí Valley [4,7]. FURB-MO: Malacological collection of Fundação Universidade Regional de Blumenau; CEMAR: Centre for Marine Studies, Bombinhas Museum and Marine Aquarium, Bombinhas/SC.

Family VERTIGINIDAE Fitzinger, 1833

Gastrocopta cf. servilis (Gould, 1843) (Figure 11)

"Estreito", Malacological region 1-Great Florianópolis, 05/04/2018, Specimen with aprox. $2.3 \mathrm{~mm}$, found in particular garden neighbor of the "Pedro Medeiros" Urban Forest Park, clinging to a wall. Credit photo \& Field report: "Jefferson Souza da Luz", DataBase Project AM [4].

BIVALVIA Linnaeus, 1758 
Citation: Agudo-Padrón Al (2020) Additions to the Systematic Inventory of Non-Marine Molluscs Occurring in the State of Santa Catarina/SC, Central Southern Brazil Region. Adv Environ Stud 4(1):261-270

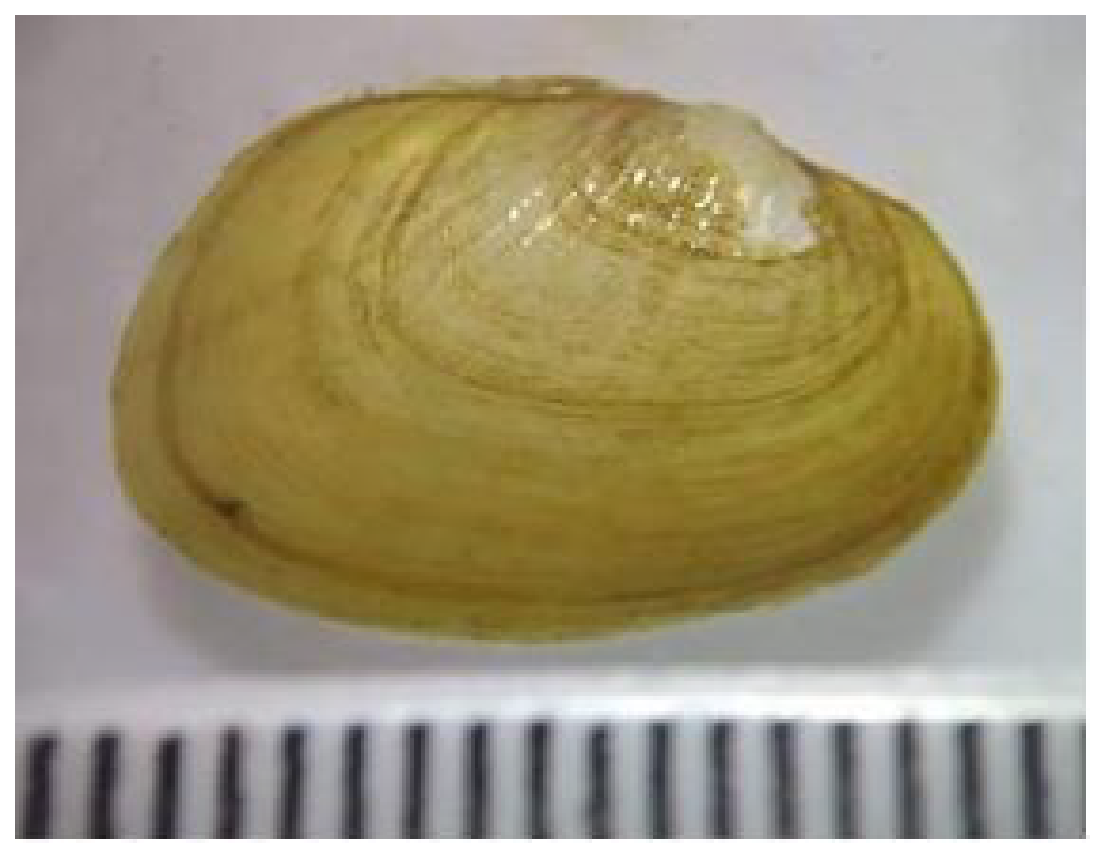

Figure 12: Native freshwater mussel/naiad Diplodon charruana (d'Orbigny, 1835).

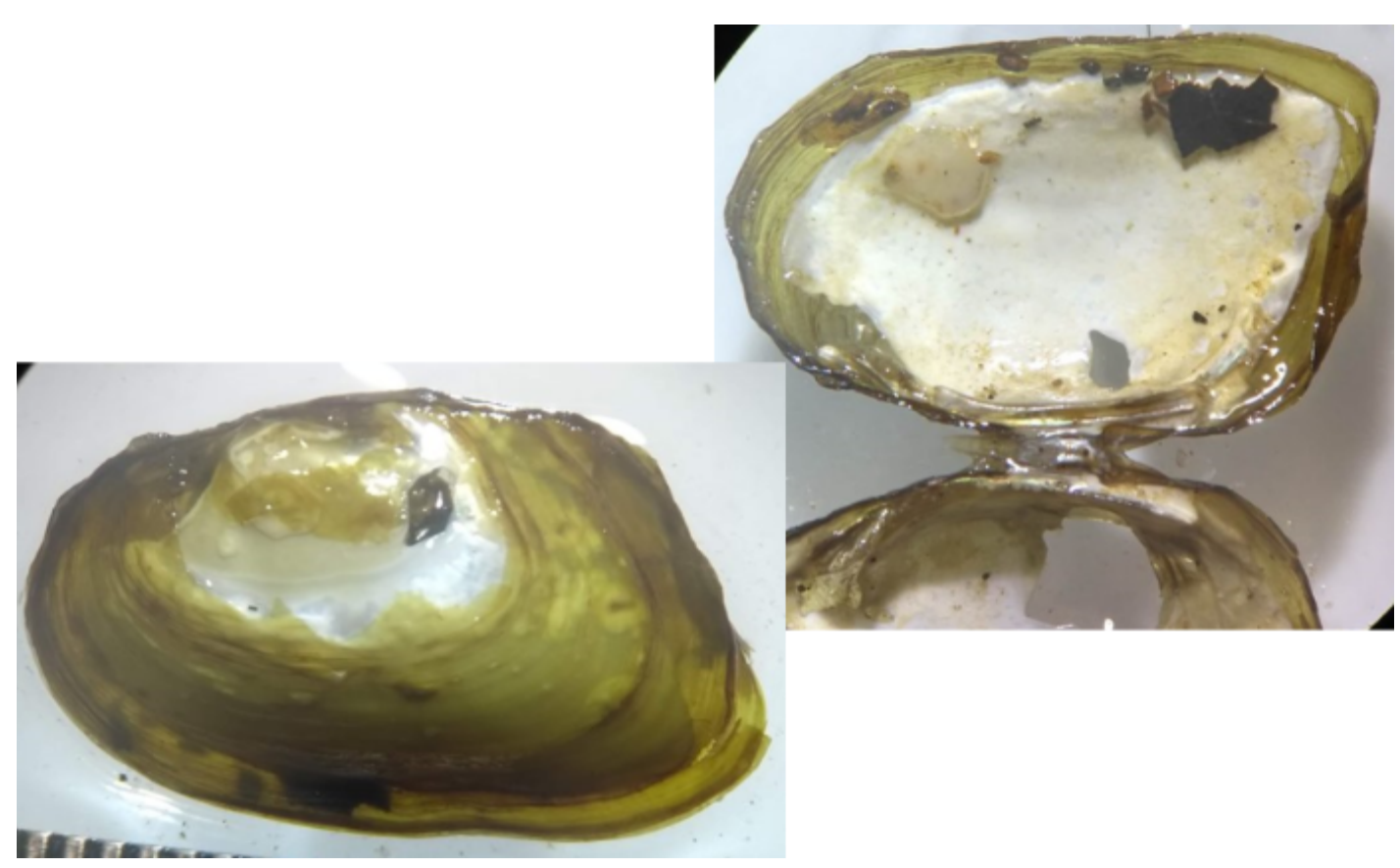

Figure 13: Native freshwater mussel/naiad Diplodon (- Rhipidodonta) suavidicus (Lea, 1856).

UNIONOIDA Stoliczka, 1871

Family HYRIIDAE Swainson, 1840

Diplodon charruana (d'Orbigny, 1835) (Figure 12)

"Benedito Novo" (Vouchers FURB-MO 357 and MO-358), Blumenau Micro-region, Malacological region 6--Itajaí Valley $[4,8]$. FURB-MO: Malacological collection of Fundação Universidade Regional de Blumenau. 13)
“Benedito Novo" (Voucher FURB-MO 366-“Benedito River" Microbasin), Malacological region 6-Itajaí Basin Valley [9]. FURB-MO: Malacological collection of Fundação Universidade Regional de Blumenau.

\section{VENEROIDA Gray, 1854}

Family CYRENIDAE Gray, 1847

Cyanocyclas paranacensis (d'Orbigny, 1835) (Figure 14)

"Mafra" ("Rio da Lança" Basin), Malacological region 2-North, 17/04/2018, Specimen with aprox. $10 \mathrm{~mm}$. Credit 
Citation: Agudo-Padrón Al (2020) Additions to the Systematic Inventory of Non-Marine Molluscs Occurring in the State of Santa Catarina/SC, Central Southern Brazil Region. Adv Environ Stud 4(1):261-270

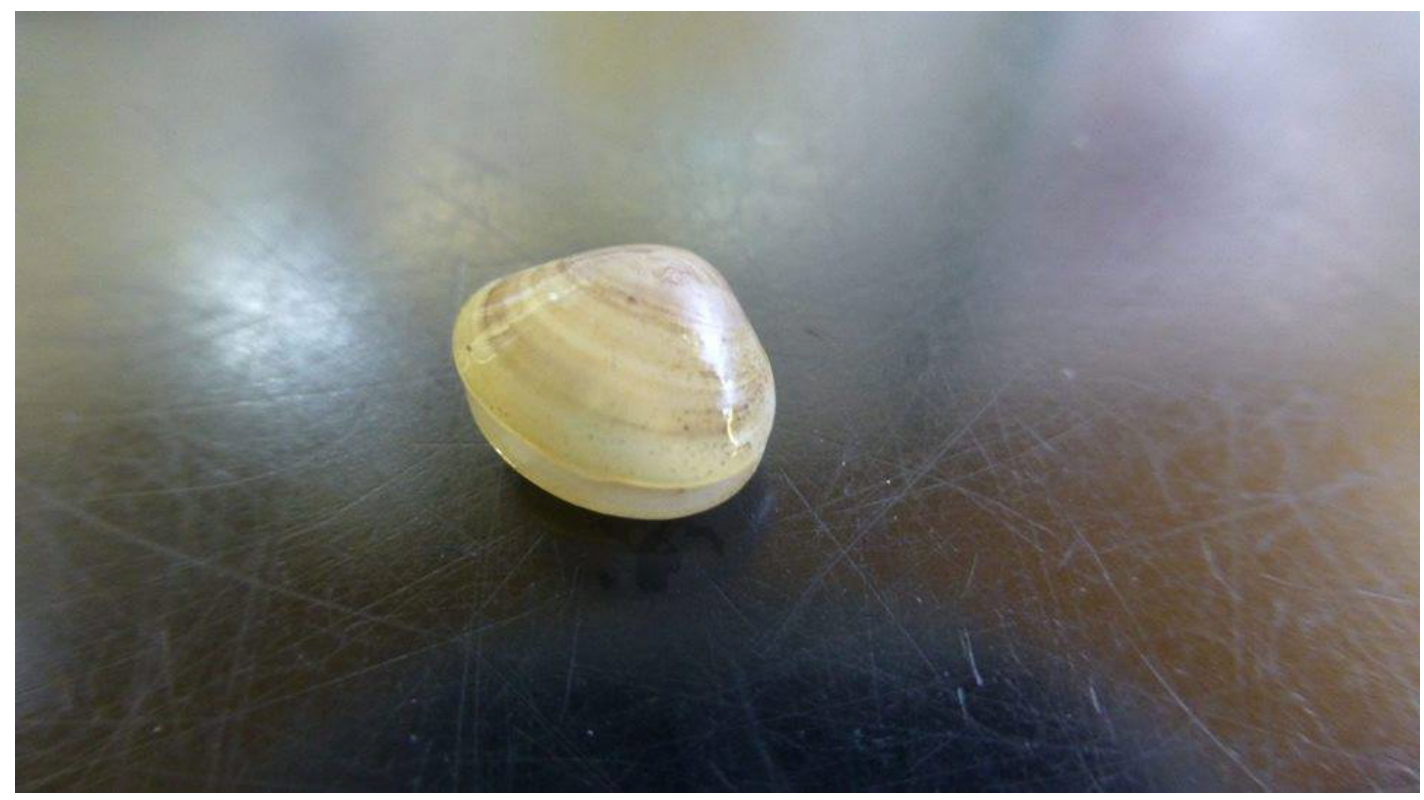

Figure 14: Native freshwater clam Cyanocyclas paranacensis (d’Orbigny, 1835).

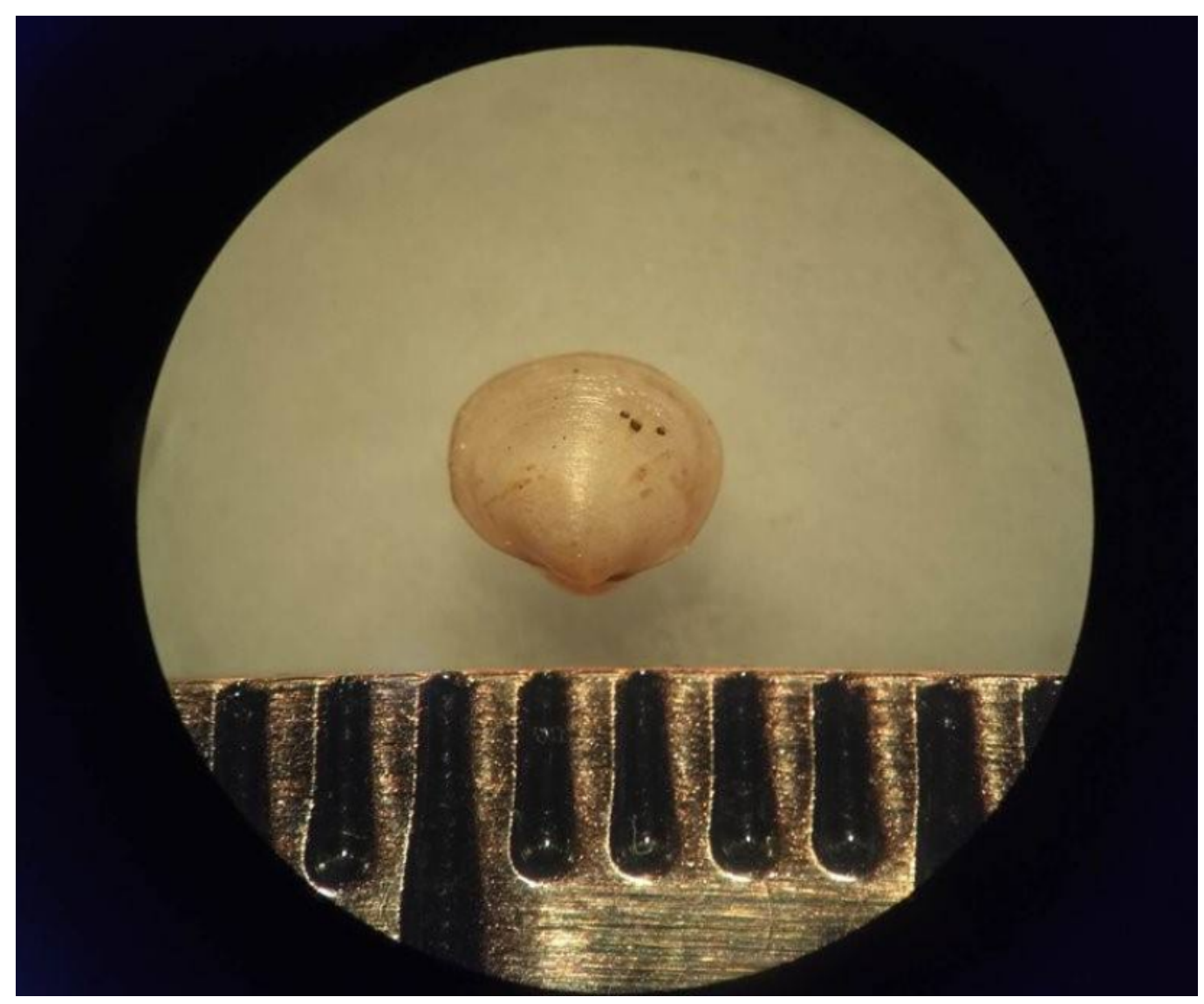

Figure 15: Native freshwater clam Musculium argentinum (d'Orbigny, 1835).

photo \& report: "Anq Marta Schafaschek", DataBase Project AM $[4,10]$

Family SPHAERIIDAE Deshayes, 1855

Musculium argentinum (d’Orbigny, 1835) (Figure 15)
"São Francisco do Sul" (Voucher FURB-MO 363-"Rio Miranda" Basin), Malacological region 2-North [11]. FURB-MO: Malacological collection of Fundação Universidade Regional de Blumenau.

Eupera bahiensis (Spix, 1827) (Figure 16) 


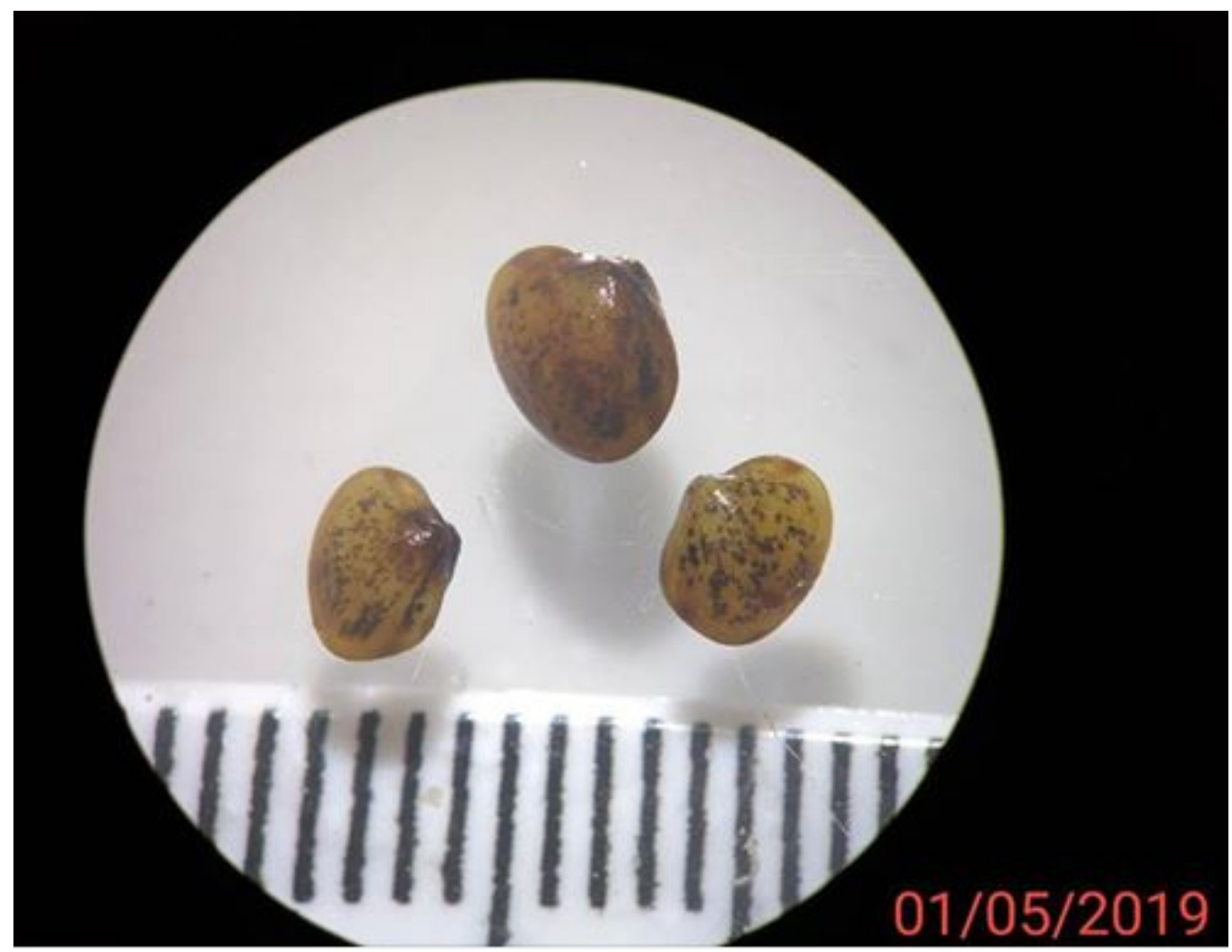

Figure 16: Native freshwater clam Eupera bahiensis (Spix, 1827).

"Guaramirim" (Voucher FURB-MO 361-"Rio Corticeirinha" Microbasin, Malacological region 2-North) \& "Benedito Novo" (Voucher FURB-MO 370-“Benedito River" Microbasin), Malacological region 6-Itajaí Basin Valley [12]. FURB-MO: Malacological collection of Fundação Universidade Regional de Blumenau.

\section{Discussion \& Conclusions}

In this new opportunity other twenty (20) non-marine/ continental mollusc species were confirmed and added to the last inventory available of Santa Catarina State/ SC (Agudo-Padrón 2018 a), increasing to 252 its number of registered forms regionally known, including today an total of 104 genera ( 91 Gastropoda \& 13 Bivalvia) and 41 families (36 Gastropoda \& 5 Bivalvia).

Additionally, soon after six (6) years of uncertainty and expectations, and based on timely observations of a bioecological nature from the follow-up of its natural life cycle (growth series/age development, from the egg/newborn to the reproductive adult), is established/revealed that the native STROPHOCHEILIDAE species Mirinaba fusoides (Bequaert, 1948) is the correct taxonomic specific identity of the mystery forest snail so far determined as AMPHIBULIMIDAE Plekocheilus (Eurytus) aff. rhodocheilus (Reeve, 1848) (Agudo-Padrón 2018 a: 56), based on young specimen occasionally photographed in the field on November 16, 2013 found in leaf litter of native Araucaria forest at "Itaiópolis" Municipal District (26²0'11"S \& 49 $\left.54^{\prime} 23^{\prime \prime} \mathrm{W}\right)$, case who clearly demonstrates (once again) the critical state of "unfamiliarity" that still prevails among us today about the bioecology and conservation status/situation of the forest non-marine molluscs occurring in the geographic territory of this State [13].

Additionally, the giant species STROPHOCHEILIDAE Megalobulimus yporanganus (Ihering \& Pilsbry, 1901) went on to replace (synonymy accepted) the previous specific status Megalobulimus toriii Morretes, 1937 [15].

Currently, the Central Southern Brazilian State of Santa Catarina/SC account with a diversity of non-marine molluscs (land/terrestrial and limnic/freshwater) comprising up to date a total of 252 species and subspecies related/registered, with 213 gastropods (166 land, 3 amphibious/limnophiles, $44 \mathrm{lim}$ nic) and 39 freshwater bivalves. Of this, 28 are exotic/non-natives (24 gastropods-1 amphibian/limnophile, 5 freshwater, 18 terrestrial-and 4 bivalves) and 25 are endemic gastropods, plus 17 forms that still require field confirmation/verification (only reported in the literature), whose territorial geo-spatial distribution has been constantly monitored and updated by us, being that their "ecological-functional" importance of it lies not only in the increasing number of taxa involved but rather in its role in the functioning of the ecosystems they occupy (... a regional aspect that is practically unknown/taken into consideration !), contributing to the cycling of nutrients in the environments where they occur, promoting the flow of matter and energy through their position in the trophic chains, either as prey of other organisms, as pollinators, as filterers and removers of water and sediments in aquatic environments (bioturbation), or as "gardeners" of forests etc etc, contributing directly and effectively to the maintenance 
Citation: Agudo-Padrón Al (2020) Additions to the Systematic Inventory of Non-Marine Molluscs Occurring in the State of Santa Catarina/SC, Central Southern Brazil Region. Adv Environ Stud 4(1):261-270

of the natural balance.

When it comes to regional research with molluscs, the Santa Catarina State/SC historically have focused their effort and interest almost uniquely in the research and development of the creation/production of marine forms capable of comercial handling. Other general aspects of their knowledge are practically ignored and/or relegated to a background (57, 58) $[1,14]$.

Ecology and natural history of neotropical land snails, by example, is almost unknown (... see our previous comment about the regional case of "mystery forest snail" !). It is necessary and urgent to recognize, valorization and attention to the study and reach of in depth knowledge about the "funtional ecological importance" of this particular biodiversity, due to its relations with the "responsiveness" to the environmental variation (bioindicators) and its impact on ecosystems processes, through weighted assessments and sober of the threat categories they currently present, as well as their spatial and altitudinal distribution in the State (... this latter work, in parallel to the systematic inventory, carried out since 1996 by us !), ... key information for answering ecological and evolutionary questions, modeling the response of the species involved to estimated anthropogenic changes for the next decades, and designing conservation strategies that are really valid for this who is one of the most vulnerable wildlife groups in our region and in Brazil in general.

\section{References}

1. Agudo-Padrón Al (2018) Revised and updated systematic inventory of non-marine molluscs occurring in the state of Santa Catarina/SC, central southern Brazil region. Advances in Environmental Studies 2: 54-60.

2. Agudo-Padrón Al (2020) First confirmed record of the polemic limnic/freshwater native apple snail AMPULLARIIDAE Pomacea maculata Perry, 1810 in Santa Catarina State/SC, Central Southern Brazil region. FMCS Newsletter Ellipsaria.

3. Coscarelli D, Montresor LC, Russo P, et al. (2018) Predicting the distribution of Omalonyx (Mollusca: Pulmonata: Succineidae) species from literature review, museum databases and new sampling efforts in Brazil. Biota Neotropica 18: 1-20.

4. Agudo-Padrón Al (2019) Conservation of non-marine molluscs in Central Southern Brasil: Recent additions to the inventory of
Santa Catarina State. IUCN/SSC Mollusc Specialist Group Newsletter Tentacle 27: 29-30.

5. Agudo-Padrón Al, Carneiro F (2018) First confirmed record of the freshwater exotic snail Lymnaeidae Galba truncatula (Müller, 1774) in Santa Catarina State/SC, Central Southern Brazil. FMCS Newsletter Ellipsaria 20: 52-53.

6. Barth JM, Martello AR (2016) Malacofauna associada à macrófita Pistia stratiotes (Araceae) em área de inundação do Rio Pintado, Bacia Hidrográfica do Iguaçu. Multiciência Online, 1-14.

7. Agudo-Padrón Al (2019) Confirmed occurrence of the invasive asiatic jumping land microsnail HELICARIONIDAE Ovachlamys fulgens (Gude, 1900) in the Southern Brazil region. Bioma 5: 1115.

8. Agudo-Padrón Al, Carneiro F (2019) First confirmed record of the limnic/freshwater native mussel/naiad Hyriidae Diplodon charruana (d'Orbigny, 1835) in Santa Catarina State/SC, Central Southern Brazil. FMCS Newsletter Ellipsaria 21: 23-25.

9. Agudo-Padrón Al, Carneiro F (2019) First confirmed record of the native limnic/freshwater mussel/naiad HYRIIDAE Diplodon (Rhipidodonta) suavidicus (Lea, 1856) in Santa Catarina State/SC, Central Southern Brazil. FMCS Newsletter Ellipsaria 21: 13-15.

10. Agudo-Padrón Al (2018) First ocurrence of the native freshwater clam Cyrenidae Cyanocyclas paranacensis (d'Orbigny, 1835) in Santa Catarina State, Central Southern Brazil. FMCS Newsletter Ellipsaria 20: 37-39.

11. Agudo-Padrón Al, Carneiro F (2019) First confirmed record of the native freshwater pea clam SPHAERIIDAE Musculium argentinum (d'Orbigny, 1835) in Santa Catarina State/SC, Central Southern Brazil. FMCS Newsletter Ellipsaria 21: 6-7.

12. Agudo-Padrón Al, Carneiro F (2019) First confirmed record of the native limnic/freshwater pea clam Sphaeriidae Eupera bahiensis (Spix, 1827) in Santa Catarina State/SC, Central Southern Brazil. FMCS Newsletter Ellipsaria 21: 8-9.

13. Agudo-Padrón Al (2020) The saga of the mysterious forest snail Plekocheilus (Eurytus) aff. rhodocheilus (Reeve, 1848) (Gastropoda: Pulmonata: Amphibulimidae) from Santa Catarina State/ SC, Central Southern Brazil region: A case of taxonomic identity resolved. Bioma 6.

14. Agudo-Padrón Al (2015) Mollusc aquaculture and malacological research in Santa Catarina State (Central Southern Brazil region): A brief synthetic critical review. Braz J Biol Sci 2: 377-380.

15. Fontenelle JH, Tomotani BM, Salvador RB (2019) Taxonomic reassessment of Megalobulimus toriii (Gastropoda, Strophocheilidae). J Conchol 43: 313-320.

DOI: $10.36959 / 742 / 222$

Copyright: (c) 2020 Agudo-Padron. This is an open-access article distributed under the terms of the Creative Commons Attribution License, which permits unrestricted use, distribution, and reproduction in any medium, provided the original author and source are credited. 